\title{
ラットにおける寒冷暴露時の肺高血圧の機序
}

\author{
樫 村 修 生 ${ }^{* 1, * 2}$ \\ ${ }^{*}{ }^{1}$ 信州豊南女子短期大学保健体育学教室 \\ *2信州大学医学部加齢適応センター・スポーツ医学教室
}

\section{Mechanisms of Cold-Induced Pulmonary Hypertension in Rats}

\author{
Osamu KASHIMURA*1,*2 \\ ${ }^{* 1}$ Department of Physical Education, Honan College, Nagano \\ ${ }^{*}$ Department of Sport Medicine, Research Center for Aging and Adaptation, \\ Shinshu University School of Medicine, Nagano
}

\begin{abstract}
The objectives of the present study are to directly measure the pulmonary and systemic arterial pressures in unanesthetized, and unrestrained rats during exposure to cold and to assess pulmonary vascular responsiveness to administration of the $\alpha$-and $\beta$-adrenergic receptor antagonists phenoxybenzamine $(1 \mathrm{mg} / \mathrm{kg}$, i.v.) and propranolol $(20 \mu \mathrm{g} / \mathrm{kg}$, i.v.), during exposure to cold. Furthermore, the rats underwent long-term exposure to cold, and pulmonary arterial pressure, systemic arterial pressure, heart rate, arterial blood gases and colonic temperature were measured. A special hand-made catheter filled with heparinized saline was inserted into the pulmonary artery via the right jugular vein, the right atrium and the right ventricle. Mean pulmonary arterial pressure was elevated during cold exposure for 2 hours. Arterial blood oxygen tension slightly decreased and carbon dioxide tension slightly rose under these conditions. The increase in cold-induced pulmonary arterial pressure was significantly lower after the administration of propranolol, but there was no change after the administration of phenoxybenzamine. However, after administrating the $\alpha$-adrenergic blocking agent a resultant increase in heart rate and fall in systemic arterial pressure during cold exposure prevented our evaluation of the pulmonary circulatory changes. These results show that $\beta$ adrenergic responsiveness of pulmonary vascular smooth muscle may have a role in the maintenance of cold-induced pulmonary hypertension.
\end{abstract}

Key words: Pulmonary arterial pressure (肺動脈圧), Catheter-implanted method (カテーテル留置法), Arterial blood gases（動脈血ガス)， $\beta$-adrenergic receptor ( $\beta$-受容体), $\alpha$-adrenergic receptor

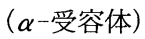

\section{はじめに}

すでに，我々は寒冷暴露時に肺高血圧が生じること， さらに，その上昇が暴露温度の低下にともない増大する
ことを報告した ${ }^{1)}$ 。高所登山の際に発生する高山病のひ とつである高地肺水腫は, 低酸素, 運動, 低温等の環境 的要因により肺高血圧を生じることが考えられる。つま り，肺動脈圧の上昇は，肺高血圧および高地肺水腫を重

Reprint requests to: Osamu Kashimura, Department of Physical Education, Honan College,

72 Nakayama, Tatsuno, Nagano, 399-04, Japan 
篤にする可能性が考えられ，寒冷暴露時の肺動脈圧の上 昇の機序を検討することは，肺高血圧や高地肺水腫を予 防するために有用なことと考える。本研究は, 覚醒状態 のラットを用い，寒冷暴露で上昇する肺高血圧の機序を 解明するため, 交感神経のアドレナリン作動性 $\alpha$-およ び $\beta$-受容体遮断剂を投与し，その影響を検討した。

\section{対象および方法}

実験には，19 週齢の Sprague-Dawley ラット雄 53 匹 （体重 578-678 g）を用いた。ラットは，ケタミン麻酔下 $(100 \mathrm{mg} / \mathrm{kg}$, i.p.) で特製カテーテル (PV-1，BOLAB, Vinyl tube) を左外頸静脈から右心房, 右心室を経由し

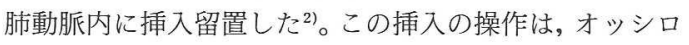
グラフによる波形モニター（日本光電，VC-23）監視下 で実施した。別のカテーテル (PE-50, 夏目, Polyethlene tube）は，右外頸動脈から大動脈弓付近まで挿入した。 各カテーテルは, 皮下を通して首背部に固定した。各力 テーテルは, 压トランスデューサー（日本光電，TP-300 T) と压アンプ (日本光電, $\mathrm{AP}-601 \mathrm{G}$ ) を接続し, 肺動 脈圧および体血圧 (以下，血圧) を測定した。心拍数は, 血圧の脈波加算出した。各血圧の測定は, 信州大学医 学部(松本市, 標高 $610 \mathrm{~m}$ ) において測定した。肺動脈圧 の 0 点 $(0 \mathrm{mmHg})$ 校正は, 右心室の位置に設定した。下 記の覚醒実験(1)抢よび(2)は, 手術終了から 12 時間以上経 過後に施行した。

（1） $0{ }^{\circ} \mathrm{C}$ 長時間暴露時の平均肺動脈圧, 平均血圧, 心拍 数および動脈血液ガスの測定

ラット 5 匹を用い, 肺動脈圧，血圧および心拍数を， 室温 $23^{\circ} \mathrm{C}$ で 10 分間測定後, 恒温室内 $0^{\circ} \mathrm{C} て ゙ 120$ 分間連続 的に測定した。また， $23^{\circ} \mathrm{C}$ 暴露下および $0{ }^{\circ} \mathrm{C}, 60$ 分間経 過時に，それぞれ血圧測定用カテーテルからそれぞれ $0.5 \mathrm{ml}$ の動脈血を採取し, 直ちに $\mathrm{pH}, \mathrm{PaO}_{2}$ および $\mathrm{PaCO}_{2}$ を血液ガス分析装置 (ラジオメータ, $\mathrm{ABL}-2$ ) で 分析した。

(2) $0{ }^{\circ} \mathrm{C}$ 暴露時のアドレナリン作動性 $\alpha-, \beta$-交感神経 遮断剤投与時の肺動脈圧，血圧および心拍数の測定

Fig. 1 に示すような環境および遮断剤投与条件を設定 し, 平均肺動脈圧, 平均血圧, 収縮期血圧, 拡張期血圧 および心拍数を連続的に測定した。

1) $23^{\circ} \mathrm{C}$ Saline : 室温 $23^{\circ} \mathrm{C} 25$ 分間暴露中, 15 分間経 過時点で生理食塩水 (容量 $0.05 \mathrm{ml}$ ) を頸静脈から肺動 脈内に投与した。

2) $0{ }^{\circ} \mathrm{C}$ Saline : 室温 $23^{\circ} \mathrm{C} 5$ 分間暴露後, 室温 $0{ }^{\circ} \mathrm{CK}$ 20 分間暴露したが, 10 分間経過時点で生理食塩水(容
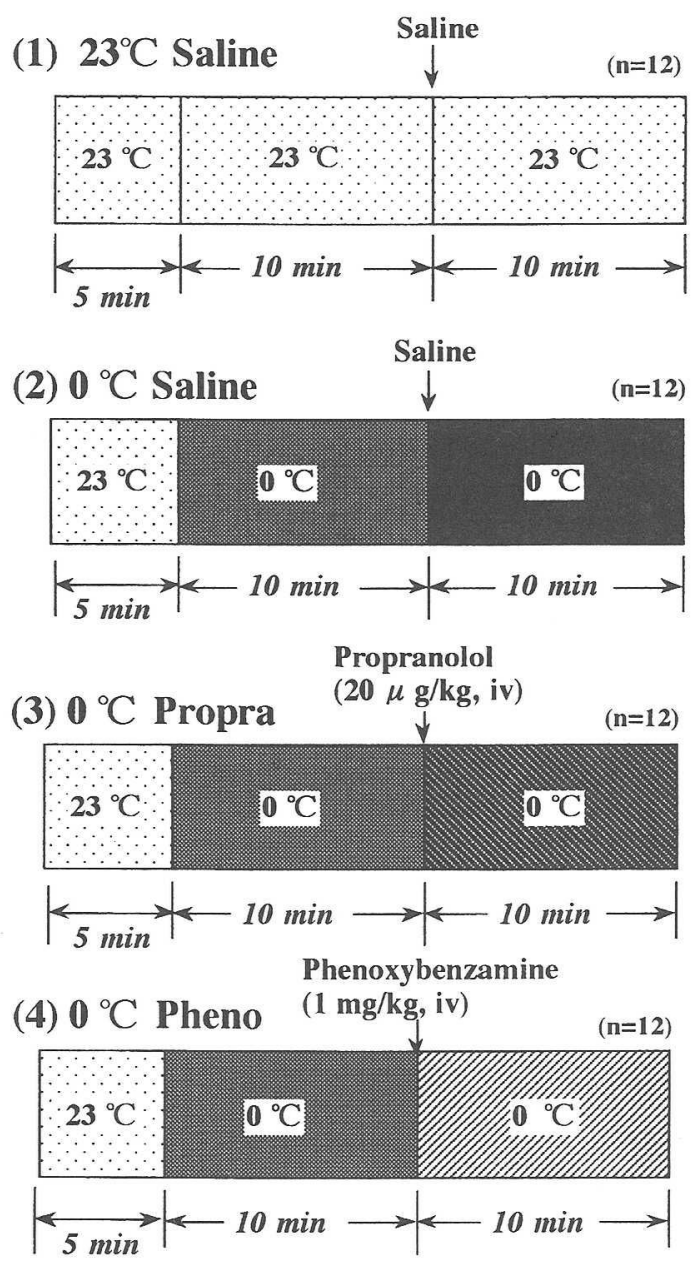

Fig. 1 Outline of the experimental design used in the 2 nd study.

The rats were randomly divided into groups for administration of saline at $23^{\circ} \mathrm{C}$ and $0^{\circ} \mathrm{C}$, propranolol at $0^{\circ} \mathrm{C}$ and phenoxybenzamine at $0^{\circ} \mathrm{C}$.

量 $0.05 \mathrm{ml}$ ）を頸静脈から肺動脈内に投与した。

3) $0^{\circ} \mathrm{C}$ Propra：室温 $23^{\circ} \mathrm{C}$ K 5 分間暴露後, 室温 $0^{\circ} \mathrm{CK}$ 20 分間暴露したが，10 分間経過時点で $\beta$-遮断剤であ る Propranolol (以下 Propra, $20 \mu \mathrm{g} / \mathrm{kg}$, i.v., 容量 0.05 ml）を頸静脈から肺動脈内に投与した。

4) $0^{\circ} \mathrm{C}$ Pheno：室温 $23^{\circ} \mathrm{C}$ に 5 分間暴露後, 室温 $0^{\circ} \mathrm{C}$ に 20 分間暴露したが, 10 分間経過時点で $\alpha$-遮断凧であ る Phenoxybenzamine (以下 Pheno, $1 \mathrm{mg} / \mathrm{kg}$, i.v., 容量 $0.05 \mathrm{ml}$ ) を頸静脈から肺動脈内に投与した。 なお, 予備実験 $(n=5)$ として, 上記の方法により, 
室温 $23^{\circ} \mathrm{C}$ おいて同量の Propra および Phenoを投与 し,その後 30 分間肺動脈圧および血圧を連続的に測定し た。

測定值は, 平均拄よび標準偏差で示し, 有意差は Friedmanの検定を用い, $\mathrm{p}<0.05$ を有意水準とした。

\section{結果}

(1) $\quad 0^{\circ} \mathrm{C}$ 長時間暴露時の血圧, 心拍数, 動脈血ガスの変化 肺動脈圧，血圧および心拍数は，それぞれ $0{ }^{\circ} \mathrm{C}$ 暴露直 後から急激に上昇し $(\mathrm{p}<0.05) ， 10$ 分から 120 分経過後 までほぼ定常状態を示した(Fig. 2, Table 1)。また， $0^{\circ} \mathrm{C}$ 暴露後 60 分経過時点での動脈血ガスおよび直腸温の変 化は，Table 2 に示した。 $0^{\circ} \mathrm{C}$ 暴露により， $\mathrm{PaO}_{2}$ は有意 $(\mathrm{p}<0.05)$ に低下したが， $\mathrm{PaO}_{2}$ は有意 $(\mathrm{p}<0.05)$ に上 昇した。しかし， $0{ }^{\circ} \mathrm{C}$ 暴露により, 動脈血 $\mathrm{pH}$ および直腸

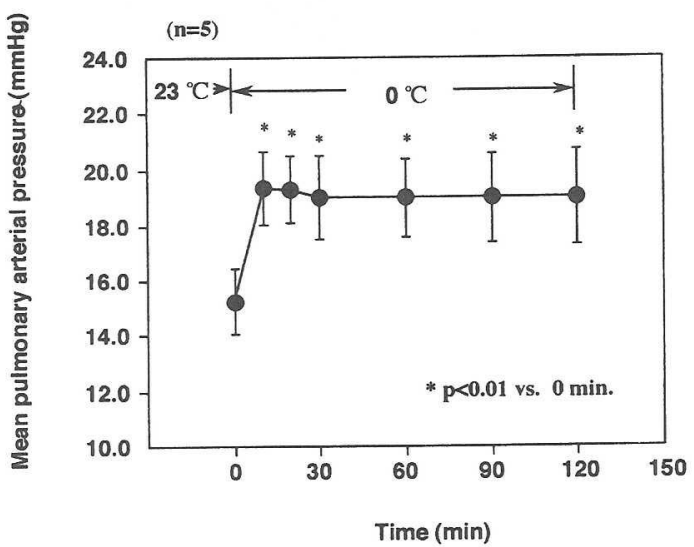

Fig. 2 Changes in mean pulmonary arterial pressure during acute exposure to $0^{\circ} \mathrm{C}$.

${ }^{*} \mathrm{P}<0.05$ vs. at $23^{\circ} \mathrm{C}$ before exposure to $0^{\circ} \mathrm{C}$.

Table 1 Changes in mean systemic arterial pressure and heart rate at exposure to $0^{\circ} \mathrm{C}$.

\begin{tabular}{rrrrrrrr}
\hline & & \multicolumn{6}{c}{ After exposure to $0^{\circ} \mathrm{C}$} \\
\cline { 3 - 8 } & & $103^{\circ} \mathrm{C}$ & $20 \mathrm{~min}$ & $30 \mathrm{~min}$ & $60 \mathrm{~min}$ & $90 \mathrm{~min}$ & $120 \mathrm{~min}$ \\
\hline Psa mean & 126 & $140^{*}$ & $141^{*}$ & $143^{*}$ & $140^{*}$ & $142^{*}$ & $135^{*}$ \\
SD & 8.6 & 7.5 & 9.2 & 8.3 & 8.3 & 8.4 & 6.7 \\
HR mean & 350 & $440^{*}$ & $446^{*}$ & $440^{*}$ & $446^{*}$ & $434^{*}$ & $446^{*}$ \\
SD & 15 & 18 & 20 & 16 & 17 & 12 & 15 \\
\hline
\end{tabular}

Psa: mean systemic arterial pressure $(\mathrm{mmHg}), \mathrm{HR}$ : heart rate (beats $/ \mathrm{min}$ ).

$\mathrm{n}=5,{ }^{*} \mathrm{p}<0.05$ vs. at $23^{\circ} \mathrm{C}$ before exposure to $0^{\circ} \mathrm{C}$.

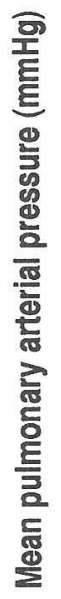

10.0

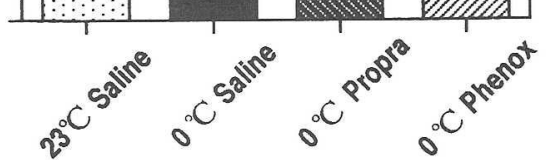

Fig.3 Mean pulmonary arterial pressor responses to administration of propranolol and phenoxybenzamine at exposure to $0^{\circ} \mathrm{C}$. ${ }^{*} \mathrm{P}<0.05$ vs. after administration of saline at exposure to $23^{\circ} \mathrm{C}$.

${ }^{*} \mathrm{P}<0.05$ vs. after administration of saline at exposure to $0^{\circ} \mathrm{C}$.

温には有意な変化がなかった。

（2） $0{ }^{\circ} \mathrm{C}$ 暴露時の $\alpha$-および $\beta$-受容体遮断風投与後の循 環動態

Fig. 3 で示すように, $0{ }^{\circ} \mathrm{C}$ Saline 時および $0{ }^{\circ} \mathrm{C}$ Pheno 時における平均肺動脈圧は, $23^{\circ} \mathrm{C}$ Saline 時の肺動脈圧よ りそれぞれ有意（p<0.05）に上昇したが， $0^{\circ} \mathrm{C}$ Propra 時の肺動脈圧は, $23^{\circ} \mathrm{C}$ Saline 時の肺動脈圧との間に差が なかった。また， $0{ }^{\circ} \mathrm{C}$ Propra 時の肺動脈圧は， $0{ }^{\circ} \mathrm{C}$ Saline 時の肺動脈圧より有意 $(\mathrm{p}<0.05)$ な低下が認めら れた。しかし， $0^{\circ} \mathrm{C}$ Pheno 時の肺動脈圧は， $0^{\circ} \mathrm{C}$ Saline

Table 2 Arterial blood gas tensions, $\mathrm{pH}$ and colonic temperature at exposure to $23^{\circ} \mathrm{C}$ and $0^{\circ} \mathrm{C}$.

\begin{tabular}{lll}
\hline & \multicolumn{1}{c}{$23^{\circ} \mathrm{C}$} & \multicolumn{1}{c}{$0{ }^{\circ} \mathrm{C}^{\star}$} \\
\hline $\mathrm{PaCO}_{2}$ (Torr) & $25.0 \pm 1.2$ & $27.1 \pm 1.5^{*}$ \\
$\mathrm{PaO}_{2}$ (Torr) & $89.0 \pm 1.8$ & $83.5 \pm 2.6^{*}$ \\
$\mathrm{pH}$ & $7.44 \pm 0.03$ & $7.42 \pm 0.04$ \\
Colonic temperature $\left({ }^{\circ} \mathrm{C}\right)$ & $37.8 \pm 0.5$ & $38.1 \pm 0.4$ \\
\hline
\end{tabular}

${ }^{\star} 60 \mathrm{~min}$ after exposure to $0^{\circ} \mathrm{C}$.

$\mathrm{n}=5$, mean $\pm \mathrm{SD},{ }^{*} \mathrm{p}<0.05$ vs, at $23^{\circ} \mathrm{C}$. 

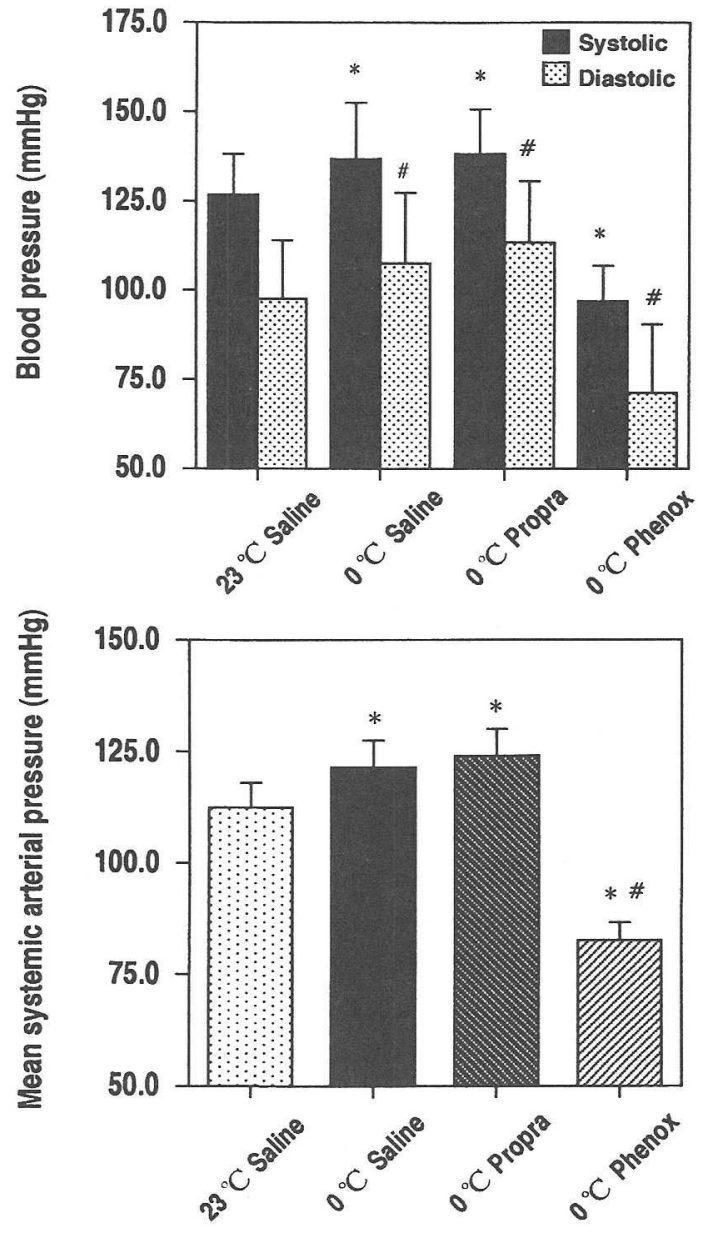

Fig. 4 Mean systemic arterial, systolic and diastolic pressor responses to administration of propranolol and phenoxybenzamine at exposure to $0^{\circ} \mathrm{C}$.

${ }^{*} \mathrm{P}<0.05$ vs. after administration of saline at exposure to $23^{\circ} \mathrm{C}$.

${ }^{*} \mathrm{P}<0.05$ vs. after administration of saline at exposure to $0^{\circ} \mathrm{C}$.

時の肺動脈圧との間に差はなかった。なお，予備実験で 行った $23^{\circ} \mathrm{C}$ Propra 投与後の肺動脈圧は, $19.1 \pm 0.8$ $\mathrm{mmHg}$ で，投与前の $15.5 \pm 0.7 \mathrm{mmHg}$ に比較して有意 $(\mathrm{p}<0.05)$ に高值を示した。心拍数は, Propra 投与後 $342 \pm 15$ beats $/ \mathrm{min}$ で，投与前の $378 \pm 7$ beats $/ \mathrm{min}$ に比 較して有意 $(\mathrm{p}<0.05)$ に低下した。また， $23^{\circ} \mathrm{C}$ Pheno 投 与 30 分後の肺動脈圧は, $11.8 \pm 1.3 \mathrm{mmHg}$ で, 投与前の $15.1 \pm 1.6 \mathrm{mmHg}$ に比較して有意（ $\mathrm{p}<0.05 ）$ に低かっ た。心拍数は，Pheno 投与後 $352 \pm 11$ beats $/$ min で，投

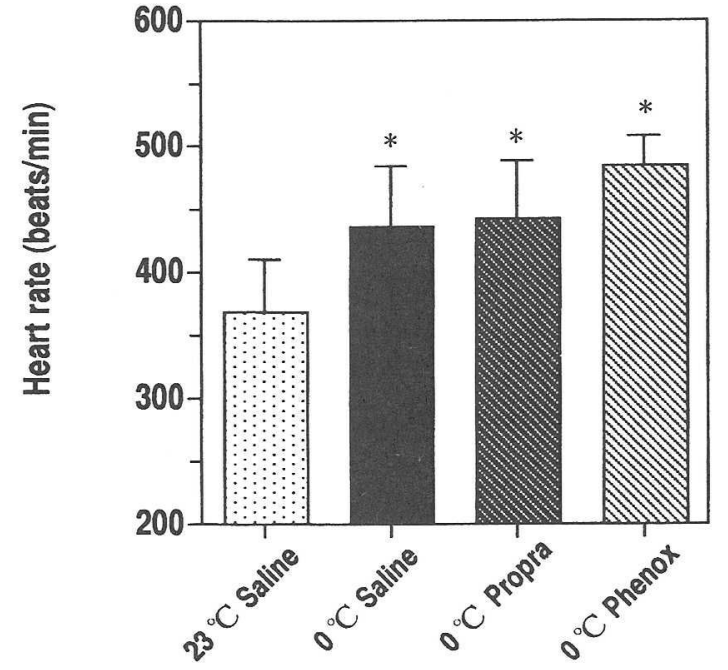

Fig. 5 Changes of heart rate induced by administrations of propranolol and phenoxybenzamine at exposure to $0^{\circ} \mathrm{C}$.

${ }^{*} \mathrm{P}<0.05$ vs. after administration of saline at exposure to $23^{\circ} \mathrm{C}$.

与前の $340 \pm 15$ beats $/ \mathrm{min}$ と差がなかった。Fig. 4 は, $0{ }^{\circ} \mathrm{C}$ 暴露時に $\alpha$-および $\beta$-受容体遮断剤投与後の平均血 圧，収縮期および拡張期圧変化を示した。平均血圧は， $23^{\circ} \mathrm{C}$ Saline 時より $0{ }^{\circ} \mathrm{C}$ Saline 時で有意 $(p<0.05)$ に高 值を示すが, $0{ }^{\circ} \mathrm{C}$ Pheno 時は有意 $(\mathrm{p}<0.05)$ に低下した。 収縮期圧は， $23^{\circ} \mathrm{C}$ Saline 時より， $0^{\circ} \mathrm{C}$ Saline 時および $0{ }^{\circ} \mathrm{C}$ Propra 時で有意 $(\mathrm{p}<0.05)$ に高值を示すが， $0{ }^{\circ} \mathrm{C}$ Pheno 時は有意 $(\mathrm{p}<0.05)$ に低下した。Fig. 5 に示すよ うに, 心拍数は, $23^{\circ} \mathrm{C}$ Saline 時より $0^{\circ} \mathrm{C}$ Saline 時で有意 $(\mathrm{p}<0.05)$ に高值を示すが, $0^{\circ} \mathrm{C}$ Propra 時は $0{ }^{\circ} \mathrm{C}$ Saline 時と差がなかった。また, 心拍数は， $0{ }^{\circ} \mathrm{C}$ Saline 時より $0{ }^{\circ} \mathrm{C}$ Pheno 時の方が有意（ $\mathrm{p}<0.05 ）$ に高值を示した。

\section{考察}

\section{（1）長時間寒冷暴露による循環動態}

寒冷暴露直後からの肺動脈圧を測定することは, 肺動 脈圧の変化を知るとともに, 寒冷暴露時での顕著な変動 がみられない時点を見つけることにある。その時点にお いて， $\alpha$-および $\beta$-受容体遮断剂を投与し，その後の変化 を観察し，寒冷暴露時の肺動脈圧の上昇に対する肺血管 $\alpha$-および $\beta$-受容体の関与を検討した。本研究において, $0{ }^{\circ} \mathrm{C}$ に 2 時間暴露時の肺動脈圧，血圧および心拍数は, 10 分間以内に急激に上昇を示し, その後は定常状態を維 
持した。つまり，(2)の測定のためには, 寒冷暴露後 10 分 経過後から血圧動態は安定しており, 薬品の投与がおこ なえる状態を確認できた。

すでに我々は, 寒冷に暴露する温度の低下にともない, 肺動脈圧が上昇することを報告しているが1)，本研究で も $0{ }^{\circ} \mathrm{C}$ 暴露時の上昇はこの報告と同程度であり,この上 昇が 2 時間定常状態を示した。寒冷暴露時の血圧および 心拍数は, 増大することが報告されている文,3)。Fregly et al. ${ }^{4)}$ によれば, $6{ }^{\circ} \mathrm{C}$ 暴露時の肺動脈圧および心拍数の変 化は, 本研究の $0{ }^{\circ} \mathrm{C}$ 暴露時とほほ同じ結果であった。 Sakai et al. ${ }^{3)}$ によれば, 緬羊において $1^{\circ} \mathrm{C}$ 暴露時の肺動 脈圧の上昇は心拍出量の増加, つまり肺血流量の増加に 関与していると報告した。本研究においては, 心拍出量 の測定を行っていないが，心拍数の増加から予測すると Sakai et al. ${ }^{3)}$ の報告と同じ結果が推測される。

\section{(2) 寒冷暴露における肺高血圧の機序}

これまで, 寒冷暴露による肺動脈圧の上昇の機序につ いては, 全容が解明されていない。摘出血管を用い冷却 した血液の灌流において, 肺動脈及び静脈は収縮するこ とを報告している5)。しかし, 本研究では, 寒冷暴露時 60 分後で結腸温が低下しないにも関わらず, 肺動脈圧が上 昇していることから間接的に血液温度の低下は関与しな いと考えられ, 同様のことが報告されている ${ }^{6)}$ 。Will et al. は, 寒冷暴露による肺動脈圧および肺血管抵抗の上 昇, 動脈血酸素分圧の低下を報告した7)。しかし, 我々の 研究では, 寒冷暴露による動脈血酸素分圧の低下はわず かであり, 低酸素性肺血管収縮による肺動脈圧の上昇は ないものと推察する。

本研究において, Fig. 3 および 4 で示すように, 寒冷暴 露により血圧および肺動脈圧の上昇が認められた。この 上昇量は, Fig. 2 および Table 1 で示す長時間寒冷暴露 時の肺動脈圧の上昇とほぼ同程度であった。寒冷暴露時 に $\alpha$-受容体遮断剂を投与したが, 肺動脈圧は有意な変 化が認められなかった。しかし，血圧は $\alpha$-遮断剤投与に より低下を示した。この体循環系の変化は, 肺循環系に も影響を与えるため, $\alpha$-受容体が急性寒冷暴露時の肺動 脈圧の上昇に関与しているかどうかは, 評価できなかっ た。我々の実験は, Will et al.により報告7されている Pheno 投与量の $1 / 3$ にし，できるだけ体循環系に変化を 与えない条件で肺循環の変化を検討しようと試みたが, Will et al. の報告7) と同じ結果になった。すでに, Pheno は, 肺循環障害を有する症例に対して肺血管床を拡張作 用させ，右心室負荷の軽減と肺水腫の予防に有用と報告 している ${ }^{8)}$ 。寒冷暴露時には熱産生が増大すると同時に, $\beta$-受容体の活性化により Cathecholamine 分泌が増大 することが示されている ${ }^{9), 10)}$ 。寒冷暴露時に上昇した肺 動脈圧は, 非選択的に $\beta$-受容体を上昇した肺動脈圧は, 非選択的に $\beta$-受容体を遮断するとされている Propra の投与により低下した。Propra の投与時のその低下は, 血圧および心拍数の顕著な変化は認められないことか ら, 寒冷暴露によって生じる肺動脈圧の上昇は, $\beta$-受容 体が関与することが明確になった。このことは，これま で一般的に言われている肺高血圧の $\alpha$-遮断剂投与によ る治療と異なり，寒冷暴露時の肺血管に生じる特異的な ものであると考える。

$23^{\circ} \mathrm{C}$ におるPhenoおよび Propra 投与の予備実験 より, $\alpha$ および $\beta$-遮断剤の薬理作用も確認された。 $23^{\circ} \mathrm{C}$ 時には $\beta$-遮断剂を投与すると, 肺動脈圧は上昇したが, 心拍数は低下した。しかし， $0{ }^{\circ} \mathrm{C}$ 時には肺動脈圧の寒冷 暴露による上昇は $\beta$-遮断剤により抑制されたが, 血圧, 心拍数には影響がなかった。このことから，寒冷暴露時 の肺動脈圧上昇には， $\beta$-受容体が関与していると考え る。しかし, Propra の投与により低下した肺動脈圧の割 合は, 寒冷暴露により上昇した肺動脈圧の平均約 $61 \%$ で あり， $\beta$-受容体以外にも関与することが推察される。今 後, さらに寒冷暴露時の肺動脈圧上昇に対する $\alpha$-刺激 剤投与効果も検討する必要がある。

\section{ま と め}

寒冷暴露により上昇する肺高血圧の機序を解明すめた め, 肺動脈内にカテーテル挿入法により覚醒状態のラッ トを用い, アドレナリン作動性 $\alpha$-および $\beta$-受容体遮断 剤を投与しその影響を検討し, 以下の結果を得た。

1 ) 平均肺動脈圧, 平均血圧および心拍数は, $0{ }^{\circ} \mathrm{C} の$ 寒 冷暴露直後から上昇し, 10 分以降その上昇が維持され た。

2） $0{ }^{\circ} \mathrm{C}$ 暴露時に $\beta$-受容体遮断剤を投与すると,上昇し た平均肺動脈圧は低下した。これは，寒冷暴露による 肺動脈圧の上昇が一部アドレナリン作動性 $\beta$-受容体 を介すると推察する。

3) $0{ }^{\circ} \mathrm{C}$ 暴露時に $\alpha$-受容体遮断剂を投与すると, 上昇 した血圧は低下し心拍数は増加を示し，肺動脈圧は変 化がなかった。このため, 寒冷暴露時の肺動脈圧上昇 に, $\alpha$-受容体が関与するかは今後の検討課題となっ た。 


\section{謝辞}

この研究に多大なご協力をいただいた信州大学医学部 環境生理学酒井秋男助教授に深謝いたします。この研究 の一部は, 文部省科学研究費将励研究 A (No.05780110) により行われた。

\section{引用文献}

1) Kashimura, O.: Effects of acute exposure to cold on pulmonary arterial blood pressure in awake rats, Jpn. J. Hyg., 48, 859-863 (1993).

2 ) Chang, S., Sakai, A. and Voelkel, N.F.: DibutrylcAMP blocks endotoxin-induced lung injury in rats, Am. Rev. Respir. Dis., 140, 1814-1817 (1989).

3 ) Sakai, A., Ueda, G., Kobayashi, T., Kubo, K., Fukushima, M. and Shibamoto, T.: Cold exposure on pulmonary circulation in conscious sheep (Abstract), 10th International Congress of Biometeorology, 225 (1984).

4 ) Fregly, M.J., Kikta, D.C., Threatte, R.M., Torres, J.L. and Barney, C.C.:Development of hypertension in rats during chronic exposure to cold, J.
Appl. Physiol., 66, 741-749 (1989).

5 ) Galleti, D.M., Salisbury, P.S. and Rielen, A.: Influence of blood temperature on the pulmonary circulation, Cir. Res., 6, 275-282 (1958).

6 ) Will, D.H., Hicks, J.L., Card, C.S., Reeves, J.T. and Alexander, A.F.: Correlation of acute with chronic hypoxic pulmonary hypertension in cattle, J. Appl. Physiol., 38, 495-498 (1975).

7 ) Will, D.H., McMertry, I.F., Reeves, J.T. and Grover, R.F.: Cold-induced pulmonary hypertension in cattle, J. Appl. Physiol., 45, 469-473 (1982).

8 ) 坂本 徹, 山田崇之：Phenoxybenzamine の肺循環 動態に及ぼす影響，胸部外科，31，285-288(1979).

9 ）樫村修生，上田五雨：運動トレーニングラットにお ける急性寒冷暴露時の体温変化, 日生気誌, 26, 125-133 (1989).

10) Estler, C.J. and Ammon, H.P.T.: The importance of the adrenergic $\beta$-receptors for thermogenesis and survival of acutely cold exposed mice, Can. J. Physiol. Pharmacol., 47, 427-434 (1969).

（受付 1994 年 5 月 16 日 受理 1994 年 11 月 7 日） 